\title{
Diffusive fluxes of phosphorus, potassium and metallic microelements as affected by soil compaction
}

\author{
Sérgio Ricardo Silva $\mathbb{D}^{a}$, Nairam Félix de Barros ${ }^{\mathrm{b}}$, Ivo Ribeiro da Silva ${ }^{\mathrm{b}}$, \\ and Nicholas Brain Comerford ${ }^{c}$ \\ aNational Wheat Research Center, Brazilian Agricultural Research Corporation (Embrapa), Passo Fundo, Brazil; \\ ${ }^{b}$ Department of Soil Science, Viçosa Federal University, Viçosa, Brazil; 'College of Tropical Agriculture and Human \\ Resources, University of Hawaii, Honolulu, USA
}

\begin{abstract}
The objective was to evaluate the effects of soil compaction on phosphorus (P), potassium (K), zinc ( $\mathrm{Zn})$, copper (Cu), iron (Fe) and manganese (Mn) diffusive fluxes. The experiment consisted of two Oxisols and eight compaction pressures. The soil samples were placed in diffusion chambers, simultaneously with two ion-exchange membranes (anionic and cationic), compressed and incubated for 20 days. The P, K, Zn, Cu, Fe, and Mn diffusive fluxes (PDF, KDF, ZnDF, CuDF, FeDF, and MnDF) were determined. The compaction decreased the PDF in the oxidic-gibbsitic soil, and increased KDF, ZnDF, CuDF, and MnDF, in both soils. There was a higher diffusion of $\mathrm{Zn}, \mathrm{Cu}$, and $\mathrm{Mn}$ in the kaolinitic than the oxidic-gibbsitic soil. The descending order of cationic-microelement diffusive flux was MnDF > ZnDF $\gg$ FeDF > CuDF. Presumably, Fe was mainly diffused as organic complexes with net negative charges, whereas $\mathrm{Zn}$ and $\mathrm{Mn}$ as free ions and, or, inorganic and organic complexes with positive charges.

Abbreviations: CuDF, cupper diffusive flux; FeDF, iron diffusive flux; KDF, potassium diffusive flux; MnDF, manganese diffusive flux; PDF, phosphorus diffusive flux; ZnDF, zinc diffusive flux; AEM, anion-exchange membrane; CEM, cation-exchange membrane
\end{abstract}

\section{ARTICLE HISTORY}

Received 21 August 2017 Accepted 2 August 2018

\section{KEYWORDS}

lon-exchange membrane; nutrient diffusion; nutrient transport; soil bulk density; soil solution

\section{Introduction}

Soil compaction caused by agricultural and forestry machinery can reduce plant growth by its adverse effect on root growth and consequent reduction in water and nutrient uptake (Ishaq et al. 2001; Medeiros, Soares, and Guimarães 2005; Silva, Barros, and Vilas Boas 2006b; Tolon-Becerra et al. 2011). Furthermore, compaction may interfere with water and nutrient transport in the soil, reducing the availability of these resources to the plants. The compaction effect on the water movement in the soil alters plant transpiration, and consequently changes the nutrient transport by mass-flow. Above a threshold level, soil compaction also reduces diffusion of some nutrients, such as phosphorus (Costa et al. 2009; Novais and Smyth 1999). Therefore, it is possible that agricultural or forest productivity may be temporarily or permanently impaired in compacted soils.

The diffusive flux is the most important process for phosphorus $(\mathrm{P})$, potassium $(\mathrm{K})$, zinc $(\mathrm{Zn})$, copper $(\mathrm{Cu})$, iron $(\mathrm{Fe})$, and manganese $(\mathrm{Mn})$ transport in soils towards the plant root due to their low concentrations in the soil solution and their high affinity with the solid phase (Barber 1995; Costa et al. 2009; Marschner 1995). This transport mechanism can be influenced by soil compaction because of its effect on the water content and impedance factors.

CONTACT Sérgio Ricardo Silva sergio.ricardo@embrapa.br N National Wheat Research Center, Brazilian Agricultural Research Corporation (Embrapa), BR 285, Km 294, PO Box 3081, Zip Code 99050-970, Passo Fundo, Rio Grande do Sul, Brazil. Color versions of one or more of the figures in the article can be found online at www.tandfonline.com/lcss. 
The diffusive flux of a solute in the soil solution, based on Fick's first law, can be written as the following equation (Eq. (1)) (Nye 1979):

$$
F D=-D A \frac{\delta \mathrm{c}}{\delta x}
$$

where FD is the diffusive flux $\left.(\mathrm{mol} \mathrm{s})^{-1}\right)$ of a solute through a surface area $\mathrm{A}\left(\mathrm{cm}^{2}\right)$, caused by the decrease of its concentration $\left(\delta \mathrm{c}, \mathrm{mol} \mathrm{cm}^{-3}\right)$ with the increase of the transport distance $(\delta \mathrm{x}, \mathrm{cm}) ; \delta \mathrm{c} / \delta \mathrm{x}$ represents the concentration gradient along the solute transport pathway, and D is the diffusion coefficient $\left(\mathrm{cm}^{2} \mathrm{~s}^{-1}\right)$ estimated according to Eq. (2) (Nye 1979):

$$
D=\operatorname{Di} \theta f \frac{\delta I}{\delta Q}
$$

where $D_{i}$ is the diffusion coefficient of the solute in water $\left(\mathrm{cm}^{2} \mathrm{~s}^{-1}\right)$, which is constant for each solute; $\theta$ is the volumetric water content $\left(\mathrm{cm}^{3} \mathrm{~cm}^{-3}\right)$; $f$ is the dimensionless soil impedance factor; $\delta \mathrm{I} / \delta \mathrm{Q}$ is the change of the intensity factor (I) of the solute in soil solution, in relation to its quantity factor (Q) in exchangeable or labile form, in balance with I. $\delta \mathrm{I} / \delta \mathrm{Q}$ is the inverse of the factor capacity (buffering capacity) of the solute in soil.

The diffusive flux may be assessed by techniques that simulate nutrient uptake by plants, such as the use of ion-exchange membranes (Bastos et al. 2008; Costa et al. 2009; Nunes et al. 2004; Oliveira et al. 2000; Pegoraro et al. 2005; Silva, Barros, and Souza 2008) or diffusive gradient in thin-films (DGT) (Degryse et al. 2009; Mason et al. 2010; Mundus et al. 2012; Tandy et al. 2011) in contact with the soil. These membranes work as nutrient sinks in soil solution, generating a concentration gradient, and thus simulating the presence of a root. Studies have shown that ions concentration in the extracts of these membranes correlates with the availability and uptake of these ions by plants (Abrams and Jarrel 1992; Durán et al. 2013; Fernandes and Warren 1996).

Despite the importance of soil compaction for nutrient transport, very few experiments have been carried out focusing on such a limitation, particularly in highly weathered soils with widespread nutrient deficiency (Fageria, Baligar, and Clark 2002). Therefore, the objective of this study was to evaluate the effects of soil compaction on diffusive fluxes of $\mathrm{P}, \mathrm{K}, \mathrm{Zn}, \mathrm{Cu}, \mathrm{Fe}$ and $\mathrm{Mn}$ in two tropical Oxisols, using an anionic and a cationic membranes, in order to better understand the nutrient transport as positively or negatively charged species.

\section{Materials and methods}

\section{Soils used in the experiment}

Samples of two Oxisols with different mineralogy collected in Santa Maria de Itabira and Santana do Paraíso counties, Minas Gerais State, Brazil, were used in the study. The first soil is a clayey oxidic-gibbsitic Typic Acrustox and the second is a clayey kaolinitic Xantic Haplustox, based on the US Soil Taxonomy [Latossolo Vermelho Amarelo ácrico (LVA) and Latossolo Amarelo distrófico (LA), respectively, to the Brazilian Soil Classification System]. These LVA and LA soils were sampled from the $0-15 \mathrm{~cm}$ layer under short-rotation eucalypt stands that were seven- and six-year-old, respectively. The samples were air-dried, sieved through a $4 \mathrm{~mm}$ mesh and homogenized for subsequent chemical and physical analysis (Table 1).

\section{Experimental design and diffusion chambers}

Eight compaction levels were tested for each soil type: 0 (control), 60, 120, 240, 360, 540, 720, and $900 \mathrm{kPa}$. These values were chosen in order to encompass tire pressures exerted on soil by distinct types of agricultural and forestry machineries. Treatments were arranged in a complete block design with five replications. The experimental unit consisted of a polyvinyl chloride (PVC) pipe $(6 \mathrm{~cm}$ in height, $4.55 \mathrm{~cm}$ internal diameter and $97.6 \mathrm{~cm}^{3}$ of storage volume), which was used to accommodate the soil plus ion-exchange membranes and thus served as a diffusion chamber. 
Table 1. Chemical and physical characteristics of the soils used in the experiment.

\begin{tabular}{|c|c|c|}
\hline Characteristic & LVA & LA \\
\hline $\mathrm{C}\left(\mathrm{g} \mathrm{kg}^{-1}\right) \dagger$ & 27.6 & 22.0 \\
\hline $\mathrm{N}\left(\mathrm{g} \mathrm{kg}^{-1}\right) \neq$ & 1.5 & 1.3 \\
\hline $\left.\mathrm{P}(\mathrm{mg} \mathrm{kg})^{-1}\right) \S$ & 0.82 & 5.65 \\
\hline $\mathrm{K}\left(\mathrm{mg} \mathrm{kg}^{-1}\right) \S$ & 25.2 & 31.9 \\
\hline $\mathrm{Ca}^{2+}\left(\mathrm{cmol}_{\mathrm{c}} \mathrm{kg}^{-1}\right)$ q & 0.2 & 1.12 \\
\hline $\mathrm{Mg}^{2+}\left(\mathrm{cmol}_{\mathrm{c}} \mathrm{kg}^{-1}\right)$ q & 0.07 & 0.17 \\
\hline $\mathrm{Zn}\left(\mathrm{mg} \mathrm{kg}^{-1}\right) \S$ & 1.47 & 3.05 \\
\hline Fe $\left(\mathrm{mg} \mathrm{kg}^{-1}\right) \S$ & 39.38 & 51.34 \\
\hline $\mathrm{Mn}\left(\mathrm{mg} \mathrm{kg}^{-1}\right) \S$ & 1.58 & 8.80 \\
\hline $\mathrm{Cu}\left(\mathrm{mg} \mathrm{kg}^{-1}\right) \S$ & 0.59 & 0.73 \\
\hline $\mathrm{pH} \#$ & 4.5 & 4.8 \\
\hline $\mathrm{FC}\left(\mathrm{kg} \mathrm{kg}^{-1}\right) \dagger \dagger$ & 0.2 & 0.2 \\
\hline$\rho\left(\mathrm{kg} \mathrm{dm}^{-3}\right) \neq \ddagger$ & 1.05 & 1.10 \\
\hline Clay $\left(\mathrm{g} \mathrm{kg}^{-1}\right)$ & 470 & 510 \\
\hline Silt $\left(\mathrm{g} \mathrm{kg}^{-1}\right)$ & 90 & 40 \\
\hline Sand $\left(\mathrm{g} \mathrm{kg}^{-1}\right)$ & 440 & 450 \\
\hline Texture & Clayey & Clayey \\
\hline $\mathrm{SiO}_{2}\left(\mathrm{~g} \mathrm{~kg}^{-1}\right) \S \S$ & 71.29 & 135.19 \\
\hline $\mathrm{Al}_{2} \mathrm{O}_{3}\left(\mathrm{~g} \mathrm{~kg}^{-1}\right) \S \S$ & 172.93 & 139.99 \\
\hline $\mathrm{Fe}_{2} \mathrm{O}_{3}\left(\mathrm{~g} \mathrm{~kg}^{-1}\right) \S \S$ & 60.64 & 44.64 \\
\hline Mineralogy & Oxidic-gibbsitic & Kaolinitic \\
\hline
\end{tabular}

† Total organic carbon.

‡ Total nitrogen.

$\S$ Mehlich-1 extractant.

I $1 \mathrm{~mol} \mathrm{~L}^{-1} \mathrm{KCl}$ extractant.

\# $\mathrm{pH}_{\text {water }}$ 1:2.5 soil:water ratio $(\mathrm{v} / \mathrm{v})$.

†† Moisture at field capacity.

㧊 Soil Bulk density.

$\S \S$ Elements in the concentrated sulfuric acid digestion.

१९ $\mathrm{x}$-ray diffraction.

Soil samples were fertilized with $\mathrm{P}\left(200 \mathrm{mg} \mathrm{dm}^{-3}\right), \mathrm{K}\left(504 \mathrm{mg} \mathrm{dm}^{-3}\right)$ and $\mathrm{Zn}, \mathrm{Cu}, \mathrm{Fe}$, and $\mathrm{Mn}$ (30 mg dm${ }^{-3}$ each). Nutrients were applied separately using two solutions, $\mathrm{K}_{2} \mathrm{HPO}_{4}$ as source of $\mathrm{P}$ and $\mathrm{K}$, and sulfates as source of $\mathrm{Zn}, \mathrm{Cu}, \mathrm{Fe}$, and $\mathrm{Mn}\left(\mathrm{ZnSO}_{4} .7 \mathrm{H}_{2} \mathrm{O}, \mathrm{CuSO}_{4} \cdot 5 \mathrm{H}_{2} \mathrm{O}, \mathrm{FeSO}_{4} .7 \mathrm{H}_{2} \mathrm{O}\right.$, and $\mathrm{MnSO}_{4} \cdot \mathrm{H}_{2} \mathrm{O}$, respectively). The nutrients were mixed throughout the soil after application, and the soil samples were maintained at rest for a period of three days to reach equilibrium after fertilization, before the start of the experiment.

The quantity of soil required to fill the volume of $97.6 \mathrm{~cm}^{3}$ was calculated to reach bulk densities of 1.05 and $1.10 \mathrm{~kg} \mathrm{dm}^{-3}$ in the LVA and LA, respectively. After that, the soil samples were weighed and moistened with deionized water to increase moisture up to field capacity $\left(0.20 \mathrm{~kg} \mathrm{~kg}^{-1}\right)$. Subsequently, the samples were placed into the diffusion chambers, simultaneously with two ion-exchange membranes (an anionic and a cationic), which were laid down horizontally on the soil, provided that the membranes were placed at 4 and $2 \mathrm{~cm}$ deep (for anionic and cationic, respectively), therefore, equidistant $2 \mathrm{~cm}$ from the edges of the diffusion chamber. Afterwards, the soils were compacted in a press equipped with dynamometer ring. After compression, the new soil bulk density and volumetric water content were calculated based on the new volume occupied by the soil and water. Finally, each chamber was wrapped with plastic film to prevent soil moisture loss, and placed in a laboratory bench at a $20 \pm 2^{\circ} \mathrm{C}$.

\section{Analysis of nutrient diffusive fluxes}

Nutrient diffusive fluxes were estimated by using two ion-exchange membranes, one anionic (AEM), positively charged (strong base type; 204UZRA; Ionics, Inc., USA), and other cationic (CEM), negatively charged (strong acid type; CR 61 CZR; Ionics, Inc., USA), as proxies for plant roots. Both measured $4.0 \mathrm{x}$ $2.5 \mathrm{~cm}$, with adsorption capacity on both faces $\left(20 \mathrm{~cm}^{2}\right)$. The membranes were conditioned and presaturated with $\mathrm{NaHCO}_{3}(1 \mathrm{~mol} \mathrm{~L}$; $12 \mathrm{~h}$ agitation) prior to use (Pegoraro et al. 2005). 
The diffusion assay was carried out during 20 days after which the chambers were disassembled. Both ion-exchange membranes were removed and gently cleaned from soil particles with deionized water. The membranes were carefully placed between filter paper to remove excess water, and then adsorbed nutrients were desorbed by shaking each membrane in individual flask with $15 \mathrm{~mL}$ of $0.5 \mathrm{~mol} \mathrm{~L}^{-1} \mathrm{HCl}$ for $1 \mathrm{~h}$. Concentrations of $\mathrm{Zn}, \mathrm{Cu}, \mathrm{Fe}$, and $\mathrm{Mn}$ in the extract were measured by atomic-absorption spectroscopy, and of $\mathrm{K}$ by flame photometry. Phosphorus concentration was determined by colorimetry, after adjusting the extract $\mathrm{pH}$ to 5.5 , with $10 \mathrm{~mol} \mathrm{~L}^{-1} \mathrm{NaOH}$ and p-nitrophenol $\mathrm{pH}$ indicator. Phosphorus, $\mathrm{K}, \mathrm{Zn}, \mathrm{Cu}, \mathrm{Fe}$, and $\mathrm{Mn}$ diffusive fluxes (PDF, KDF, $\mathrm{ZnDF}, \mathrm{CuDF}, \mathrm{FeDF}$, and $\mathrm{MnDF}$ ) were determined taking into account the amount of nutrients transported and adsorbed to each membrane, per unit of area and time $\left(\mu \mathrm{mol} \mathrm{m} \mathrm{min}^{-1}\right)$.

\section{Statistical analysis}

The experimental results were analyzed by the GENES ${ }^{\circledast}$ statistical packages (Cruz 2013). The data for each soil type (LVA and LA), individually, were subjected to Lilliefors' test for testing normality, and to Bartlett's test for testing homogeneity of variance. Skewness and kurtosis coefficients were also evaluated. Since all assumptions required for a valid statistical analysis were met, Analysis of Variance (ANOVA) was performed. When the ANOVA resulted in a significant $P$ value $(P \leq 0.05)$, the quantitative parameters were adjusted by linear, quadratic, and quadratic base of square root models of linear regression, using the $\mathrm{SAEG}^{\circledast}$ statistical packages (Euclydes 1983). The coefficients of the adjusted models were assessed by the F-test (at significance levels of $P<0.001$, $P<0.01$ and $P<0.05)$ considering the mean square error of ANOVA of the experiment. Finally, among two or more models with statistically significant coefficients, the one with the higher coefficient of determination $\left(\mathrm{R}^{2}\right)$ was chosen.

\section{Results and discussion}

\section{Soil bulk density and volumetric water content}

Soil bulk density ( $\rho$ ) increased up to $29.5 \%$ and $35.1 \%$ in the LVA and LA, respectively, in response to the compression applied (Figure 1). It was found that the lowest applied pressure $(60 \mathrm{kPa})$ increased $\rho$ by $9.5 \%$ and $17.1 \%$ in the LVA and LA, respectively, with gradual increases as the pressure was applied. The higher LVA physical resistance to compaction, as compared to the LA, can be attributed to its oxidic-gibbsitic mineralogy, because the $\mathrm{Fe}$ and $\mathrm{Al}$ oxides, which are predominant in its composition (Table 1), are associated with silicate clays, resulting in small and extremely stable aggregates (Silva, Barros, and Costa 2006a).
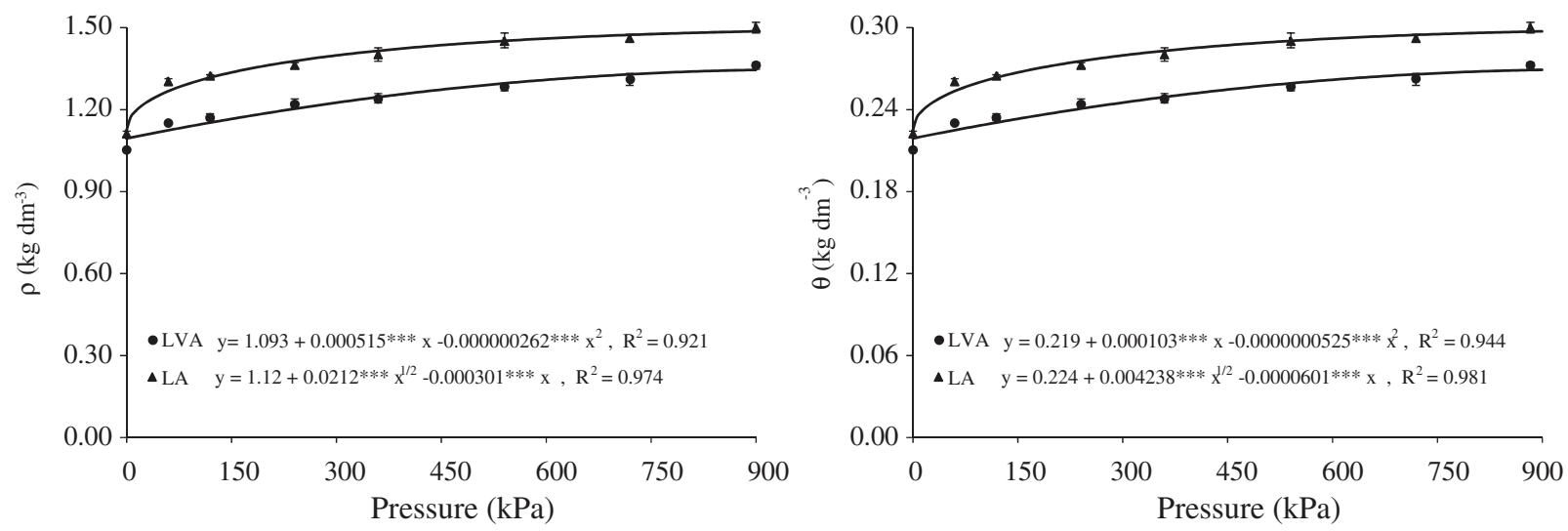

Figure 1. Soil bulk density $(\rho)$ and volumetric water content $(\theta)$ in two Oxisols (LVA and LA) compacted at different pressures. (***: significance of the coefficients of the adjusted models by F-test, at $P<0.001)$. Error bars are $95 \%$ confidence interval for the mean $(n=5)$ for each pressure in each soil. 
Despite the gravimetric moisture remaining the same throughout the test $\left(0.20 \mathrm{~kg} \mathrm{~kg}^{-1}\right)$, the volumetric water content $\left(\theta, \mathrm{kg} \mathrm{dm}^{-3}\right)$ increased in the same magnitude as $\rho$ as a result of the volume reduction caused by soil compression levels (Figure 1). Soil compaction leads to porous system modification, usually reducing total porosity and increasing microporosity. Silva, Barros, and Costa (2006a) found microporosity increases in response to compaction in two Oxisols, which resulted in increased water retention at 0.01 and $15 \mathrm{MPa}$ (field capacity and permanent wilting point, respectively), on both a gravimetric and a volumetric basis, and they concluded that soil compaction promoted the formation of pores with smaller diameter where water is predominantly retained.

\section{Diffusive fluxes of the macronutrients phosphorus and potassium}

There was PDF only in the positively charged AEM (Figure 2). PDF decreased on average by $83 \%$ (across pressure levels) in the LVA in response to the soil compaction, when compared to that in the uncompressed control soil. The $60 \mathrm{kPa}$ pressure promoted PDF reduction by $76.5 \%$, which means it accounted for over $92 \%$ of the average PDF decrease previously mentioned. Novais and Smyth (1999) hypothesized that compaction was expected to reduce the diffusion of P in tropical soils with high capacity for anions sorption, because soil compression can bring phosphate in the soil solution nearer the soil adsorption/fixation surface. However, PDF was not significantly modified by soil compaction in LA, which can be attributed to the stronger $\mathrm{P}$ adsorption to soil colloids (Figure 2). This higher strong $\mathrm{P}$ adsorption in the kaolinitic soil (LA) was not expected, since more oxidic soils have higher P adsorption capacity than kaolinitic ones (Bastos et al. 2008; Novais and Smyth 1999).

There was KDF only in the negatively charged CEM (Figure 2). KDF increased up to $31.2 \%$ and $19.7 \%$ in the LVA (pressure $=900 \mathrm{kPa}$ ) and LA (pressure $=360 \mathrm{kPa}$ ), respectively, in response to the soil compaction. This increase in KDF can be attributed to the increase in $\rho$, as a result of soil compaction
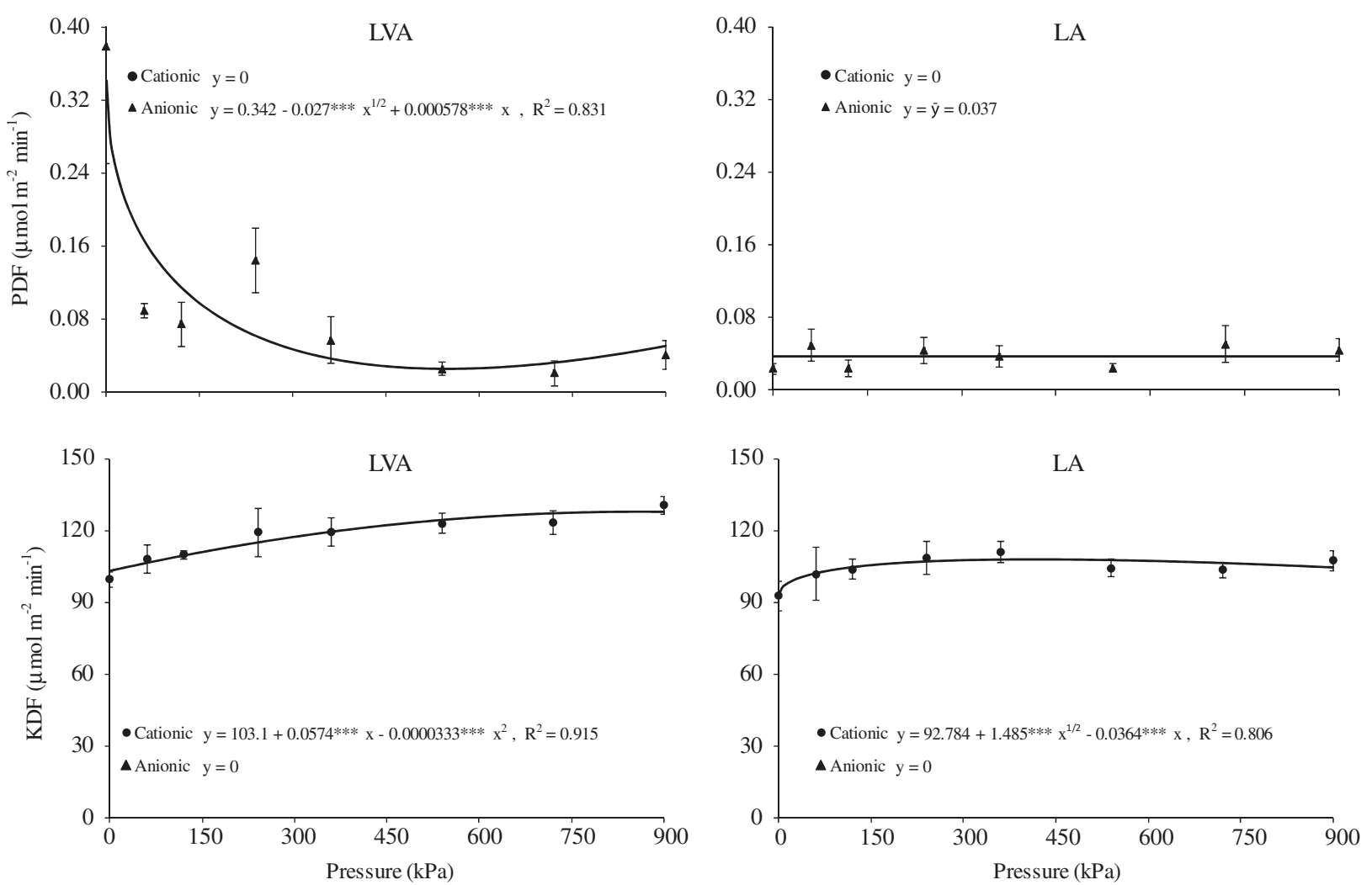

Figure 2. Diffusive fluxes of $P$ (PDF) and K (KDF) to a negatively charged cation-exchange membrane (black dots) or a positively charged anion-exchange membrane (black triangles) in two Oxisols (LVA and LA) compacted at different pressures. (***: significance of the coefficients of the adjusted models by F-test, at $P<0.001)$. Error bars are $95 \%$ confidence interval for the mean $(n=5)$ for each pressure and membrane. 
(Figure 1). According to Warncke and Barber (1972), diffusion become progressively greater by increasing $\rho$, until it reaches a maximum and then it decreases by applying higher pressures. This initial increase in KDF is because compaction brings soil particles closer, which favors water film continuity and decreases the distance that $\mathrm{K}^{+}$ions have to move to reach the surface of the cation-exchange membrane. Changes in ions diffusive fluxes when a soil is subjected to compaction levels sufficient to increase $\rho$ are assigned to shifts in soil impedance factor (f, Eq. (2)), which involves the tortuosity (Costa et al. 2009). Warncke and Barber (1972) observed that this kind of tortuosity was reduced with increasing $\rho$, therefore, causing reduction in the diffusion distance.

Another mechanism that contributed to increase KDF was the increase in volumetric water content $(\theta$, Eq. (2)) as a result of soil compaction (Figure 1), as verified by Silva, Barros, and Costa (2006a) in an experiment with two tropical Oxisols. Soil moisture influences ion partition between liquid and solid phases, increasing $\delta \mathrm{I} / \delta \mathrm{Q}$ ratio, and, as a consequence, the value of $\mathrm{D}$ (Eq. (2)). Costa et al. (2009) reported that the increase in $\theta$, and, consequently, in the water thickness inside the pores, increased KDF. They concluded that moisture influenced more intensely KDF than the compaction applied in three tropical Oxisols used in their experiment.

\section{Diffusive fluxes of zinc, copper, iron, and manganese}

Soil compaction increased diffusive fluxes of $\mathrm{Zn}, \mathrm{Cu}, \mathrm{Fe}$, and $\mathrm{Mn}$ in most cases (Figure 3). Increases in diffusive fluxes of these elements can be attributed to the effects of $\rho$ and $\theta$ increments in compacted soils, as previously discussed to KDF.

There was diffusion of $\mathrm{Zn}, \mathrm{Cu}, \mathrm{Fe}$, and $\mathrm{Mn}$ to both exchange membranes, AEM and CEM (except $\mathrm{Zn}$ in LVA) (Figure 3). Despite these elements being found in soil solution as free ions or inorganic cationic species (examples: $\mathrm{Zn}^{2+}, \mathrm{ZnOH}^{+} ; \mathrm{Cu}^{2+}, \mathrm{CuOH}^{+} ; \mathrm{Fe}^{3+}, \mathrm{Fe}^{2+}, \mathrm{FeOH}^{2+}, \mathrm{Fe}(\mathrm{OH})_{2}^{+} ; \mathrm{Mn}^{2+}, \mathrm{Mn}^{4}$ $\left.{ }^{+}, \mathrm{Mn}(\mathrm{OH})^{+}, \mathrm{MnCl}^{+}\right)$, they can form soluble complexes in water with organic ligands (i.e., humic and fulvic acids, and low-molecular-weight organic acids, such as citrate, malate, oxalate, malonate, and acetate) (Degryse et al. 2009; Pegoraro et al. 2005; Ryan, Delhaize, and Jones 2001; Stevenson and Ardakani 1972), which can present net negative charges and thus be adsorbed in the positively charged AEM. Metal chelation and complexation mechanisms are very important in soil, because they may increase the solubility of some metallic cations, and, consequently, their mobility by both diffusion and mass flow. Soluble organometallic compounds are often the main species of microelements in soil solution, and enhance their transport to the roots (Pegoraro et al. 2005; Ryan, Delhaize, and Jones 2001).

The ZnDF towards the negatively charged CEM increased up to $74 \%$ and $89 \%$ in the LVA and LA, respectively, in response to soil compaction (Figure 3). Silva, Barros, and Souza (2008) also achieved increases of $\mathrm{ZnDF}$ in two compacted tropical Oxisols, where the observed increments were more substantial in the clayey soil than in the sandy one. However, $\mathrm{ZnDF}$ assessed by the positively charged AEM was zero in the LVA or too low in the LA. These results suggest that Zn compounds with net positive charges are those predominantly transported in the soil, as previously observed by Pegoraro et al. (2005) and Pegoraro et al. (2006). Degryse et al. (2009) and Nolan, Mclaughlin, and Mason (2003) stated that Zn occurs mainly as free ions in soil solution at low pH (unless there are elevated concentrations of inorganic ligands that may form complexes), but a considerable fraction may be complexed with dissolved organic matter at $\mathrm{pH}>6.5$.

The CuDF towards the negatively charged CEM increased up to $40.2 \%$ and $68.7 \%$ in the LVA (pressure $=240 \mathrm{kPa}$ ) and LA (pressure $=360 \mathrm{kPa}$ ), respectively, in response to the soil compaction (Figure 3). In turn, CuDF towards the positively charged AEM increased up to $69.7 \%$ in the LA (pressure $=900 \mathrm{kPa}$ ), and there were no significant effects of compaction on $\mathrm{CuDF}$ in the LVA. Copper compounds with net positive charges moved in greater quantity towards the negatively charged membranes, since $\mathrm{CuDF}$ to $\mathrm{CEM}$ was on average 3.8 and 5.7 times higher than CuDF to AEM, in the LVA and LA, respectively. Pegoraro et al. (2005) and Pegoraro et al. (2006) obtained distinct results, where CuDF was higher to AEM than to CEM, in 

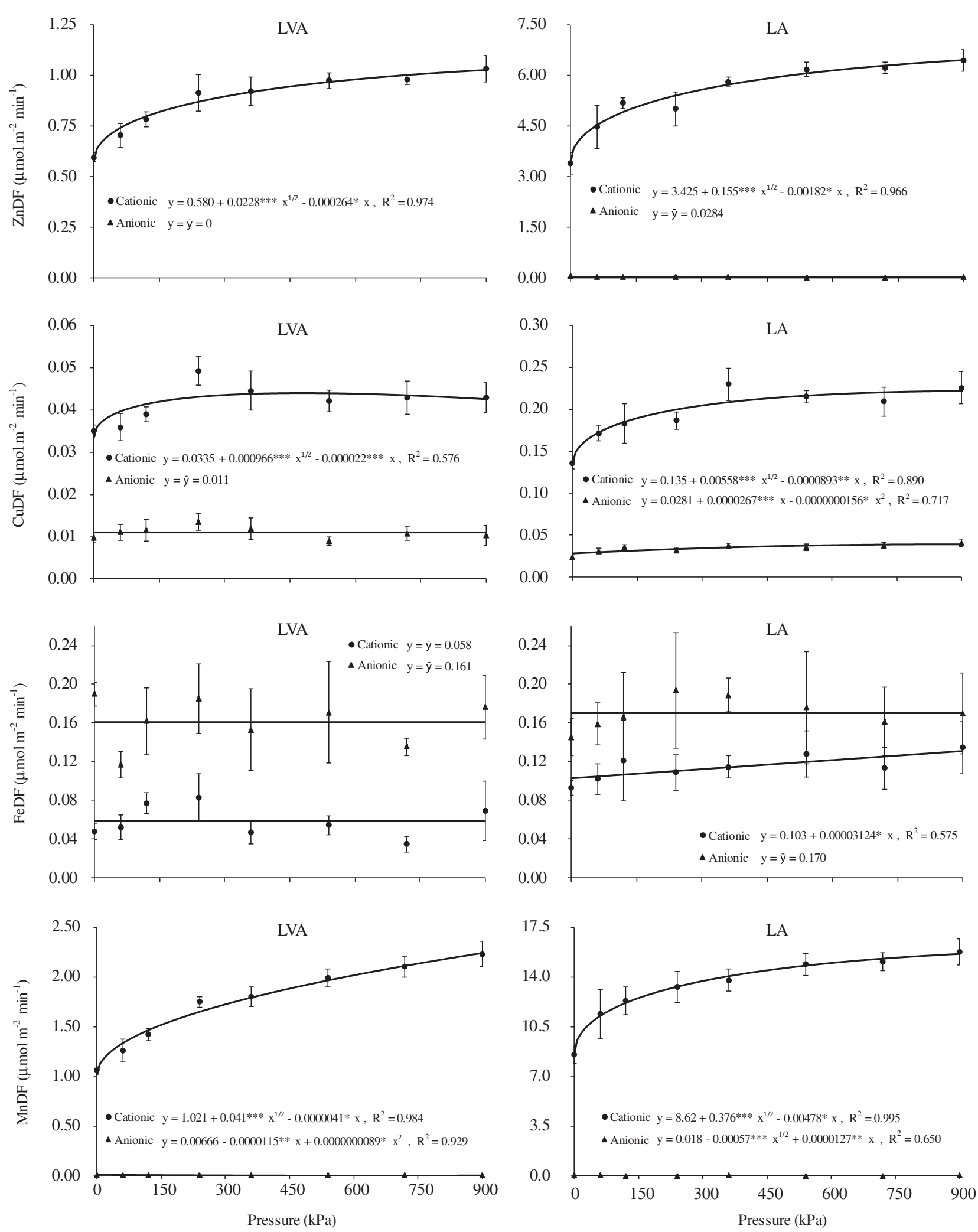

Figure 3. Diffusive fluxes of $\mathrm{Zn}(\mathrm{ZnDF}), \mathrm{Cu}(\mathrm{CuDF}), \mathrm{Fe}(\mathrm{FeDF})$ and $\mathrm{Mn}(\mathrm{MnDF})$ to a negatively charged cation-exchange membrane (black dots) or a positively charged anion-exchange membrane (black triangles) in two Oxisols (LVA and LA) compacted at different pressures. ${ }^{* * *},{ }^{* *}, *$, significance of the coefficients of the adjusted models by F-test, respectively, at $P<0.001, P<0.01$, $P<0.05)$. Error bars are $95 \%$ confidence interval for the mean $(n=5)$ for each pressure in each soil and membrane.

two Oxisols (a clayey and a silt-loam soils). Such differences may be related to the availability of organic ligands readily available to bind $\mathrm{Cu}$ in the soil solution. According to Nierop et al. (2002) and Nolan, Mclaughlin, and Mason (2003), $\mathrm{Cu}$ is usually present in soil solution 
complexed with dissolved organic matter (DOM), since $\mathrm{Cu}$ has high affinity for these organic ligands.

The FeDF towards the negatively charged CEM increased up to $17 \%$ in the LA, in response to the soil compaction (Figure 3). For other instances (FeDF to AEM in the LA, and to both membranes in the LVA) there were no significant differences among compaction levels. Distinctly from others assessed microelements, the results indicate that Fe compounds with net negative charges moved preferentially to the positively charged membrane as judged from FeDF to AEM, which was on average 2.8 and 1.5 times greater than FeDF to the negatively charged CEM, in the LVA and LA, respectively. Similar results were verified by Pegoraro et al. (2005) and Pegoraro et al. (2006), who also observed greater FeDF as negatively charged species in two Oxisols, especially under conditions of greater availability of low molecular weight organic ligands.

The MnDF towards the negatively charged CEM increased up to $111 \%$ and $85 \%$ in the LVA and LA, respectively, in response to the soil compaction (Figure 3). The results of this essay indicate that $\mathrm{Mn}$ compounds with net positive charges are the dominant species being transported to the membranes. In fact, MnDF to the CEM was on average 379 and 993 times greater than MnDF to the AEM, in the LVA and LA, respectively. These results are corroborated by Pegoraro et al. (2005) and Pegoraro et al. (2006), who achieved a higher MnDF to a negatively charged CEM than to AEM, in two Oxisols.

Diffusive fluxes of $\mathrm{Zn}, \mathrm{Cu}$, and $\mathrm{Mn}$ were significantly higher in the LA than in the LVA (Figure 3). This can be attributed to the higher original levels (before fertilization) of these nutrients in the LA, and because the LVA has higher organic matter content and more oxidic mineralogy (Table 1), consequently with higher adsorption capacity for metals (lower $\delta \mathrm{I} / \delta \mathrm{Q}$, Eq. (2)).

Manganese and $\mathrm{Zn}$ had higher diffusive fluxes, most likely due to weaker adsorption of these nutrients by soil colloids or the presence of poorly crystalline oxides bearing those elements. These results are supported by Pegoraro et al. (2005), who observed that Mn was the cationic element that had the largest diffusive flux, and its transport was less dependent upon the organometallic complexes formation. A similar pattern was also evident for $\mathrm{Zn}$, according to these authors. On the other hand, $\mathrm{Cu}$ had the lowest diffusive flux and it could have resulted from its higher affinity for soil organic matter (SOM) (Temminghoff, Van Der Zee, and DeHaan 1997) and, or, its strong association with $\mathrm{Fe}$ and $\mathrm{Al}$ oxides.

Last, but not least, the results of the current study indicate the need for simultaneous use of cationic and anionic exchange membranes for more accurate assessment of metallic microelement diffusive flux in soils. This is particularly true if $\mathrm{Fe}$ and $\mathrm{Cu}$ are the elements of interest since significant proportions of them seem to be transported as species or complexes with net negative charges.

\section{Conclusions}

Results of this research showed that soil compaction can reduce the diffusive flux of $\mathrm{P}$ and increase that of $\mathrm{K}, \mathrm{Zn}, \mathrm{Cu}, \mathrm{Fe}$, and $\mathrm{Mn}$. The diffusive fluxes of $\mathrm{Zn}, \mathrm{Cu}$, and $\mathrm{Mn}$ were substantially higher in the kaolinitic soil (LA) than in the oxidic-gibbsitic (LVA). In our case study, the descending order of cationic-microelement diffusive flux was $\mathrm{MnDF}>\mathrm{ZnDF} \gg$ FeDF $>$ CuDF. The cationic microelements were transported in soil solution as forms presenting positive or negative net charges as judged from the nutrient diffusion to cationic or anionic membranes, respectively. Presumably, Fe was mainly diffused as organic complexes with net negative charges, whereas $\mathrm{Zn}$ and $\mathrm{Mn}$ as free ions and, or, inorganic and organic complexes with positive charges. The importance of taking into account the negatively charged species for metals believed to be transported in the soil only as cationic species should not be overlooked. The role of compaction in influencing diffusion can be estimated by the effect that compaction has in the water content and impedance factors. 


\section{ORCID}

Sérgio Ricardo Silva (D) http://orcid.org/0000-0001-6951-8324

\section{References}

Abrams, M. M., and W. N. Jarrel. 1992. Bioavailability index for phosphorus using ion exchange resin impregnated membranes. Soil Science Society of American Journal 56:1532-37. doi:10.2136/sssaj1992.03615995005600050033x.

Barber, S. A. 1995. Soil nutrient bioavailability: A mechanistic approach. 2nd ed. New York, USA: John Wiley \& Sons.

Bastos, A. L., J. P. V. Costa, I. F. Silva, R. W. C. Raposo, and J. S. Souto. 2008. Influence of phosphorus doses in diffusive flow in the soils of Alagoas. Revista Brasileira de Engenharia Agrícola e Ambiental 12:136-42. doi:10.1590/ S1415-43662008000200005.

Costa, J. P. V., N. F. Barros, A. L. Bastos, and A. W. Albuquerque. 2009. Influence of water content and soil compaction on the potassium diffusion flow into soil. Revista Brasileira de Engenharia Agrícola e Ambiental 13:56-62. doi:10.1590/S1415-43662009000100008.

Cruz, C. D. 2013. GENES - a software package for analysis in experimental statistics and quantitative genetics. Acta Scientiarum. Agronomy 35:271-76. doi:10.4025/actasciagron.v35i3.21251.

Degryse, F., E. Smolders, H. Zhang, and W. Davison. 2009. Predicting availability of mineral elements to plants with the DGT technique: A review of experimental data and interpretation by modelling. Environmental Chemistry 6:198-218. doi:10.1071/EN09010.

Durán, J., M. Delgado-Baquerizo, A. Rodríguez, F. Covelo, and A. Gallardo. 2013. Ionic exchange membranes (IEMs): A good indicator of soil inorganic N production. Soil Biology and Biochemistry 57:964-68. doi:10.1016/j. soilbio.2012.07.016.

Euclydes, R. F. 1983. Manual de utilização do programa SAEG (Sistema para Análises Estatísticas e Genéticas). Viçosa, Brazil: Viçosa Federal University Press.

Fageria, N. K., V. C. Baligar, and R. B. Clark. 2002. Micronutrients in crop production. Advances in Agronomy 77:189272. doi:10.1016/S0065-2113(02)77015-6.

Fernandes, M. L. V., and G. P. Warren. 1996. Comparison of resin beads and resin membranes for extracting soil phosphate. Fertilizer Research 44:1-8. doi:10.1007/BF00750686.

Ishaq, M., M. Ibrahim, A. Hassan, M. Saeed, and R. Lal. 2001. Subsoil compaction effects on crops in Punjab, Pakistan: II. Root growth and nutrient uptake of wheat and sorghum. Soil and Tillage Research 60:153-61. doi:10.1016/S01671987(01)00177-5.

Marschner, H. 1995. Mineral nutrition of higher plants. 2nd ed. San Diego, USA: Academic Press.

Mason, S., A. Mcneill, M. J. Mclaughlin, and H. Zhang. 2010. Prediction of wheat response to an application of phosphorus under field conditions using diffusive gradients in thin-films (DGT) and extraction methods. Plant and Soil 337:243-58. doi:10.1007/s11104-010-0521-0.

Medeiros, R. D., A. A. Soares, and R. M. Guimarães. 2005. Soil compaction and water management. I: Effects upon uptake of N, P, K, root and shoot dry matter of rice plants. Ciência e Agrotecnologia 29:940-47. doi:10.1590/S141370542005000500004.

Mundus, S., E. Lombi, P. E. Holm, H. Zhang, and S. Husted. 2012. Assessing the plant availability of manganese in soil using diffusive gradients in thin films (DGT). Geoderma 183/184:92-99. doi:10.1016/j.geoderma.2012.03.014.

Nierop, K. G. J., B. Jansen, J. A. Vrugt, and J. M. Verstraten. 2002. Copper complexation by dissolved organic matter and uncertainty assessment of their stability constants. Chemosphere 49:1191-200. doi:10.1016/S0045-6535(02)00504-0.

Nolan, A. L., M. J. Mclaughlin, and S. D. Mason. 2003. Chemical speciation of $\mathrm{Zn}, \mathrm{Cd}, \mathrm{Cu}$ and $\mathrm{Pb}$ in pore waters of agricultural and contaminated soil using donnan dialysis. Environmental Science \& Technology 37:90-98. doi:10.1021/es025966k.

Novais, R. F., and T. J. Smyth. 1999. Fósforo em solo e planta em condições tropicais. Viçosa, Brazil: Federal Viçosa University Press.

Nunes, F. N., R. F. Novais, I. R. Silva, F. O. Gebrim, and J. F. B. São José. 2004. Diffusive flux of iron in soils influenced by phosphorus rates and levels of acidity and moisture. Revista Brasileira de Ciência do Solo 28:423-29. doi:10.1590/ S0100-06832004000300003.

Nye, P. H. 1979. Diffusion of ions and uncharged solutes in soils and clays. Advances in Agronomy 31:225-72. doi:10.1016/S0065-2113(08)60141-8.

Oliveira, F. H. T., R. F. Novais, T. J. Smyth, and J. C. L. Neves. 2000. Aluminum diffusion in oxisols as influenced by soil water matric potential, $\mathrm{pH}$, lime, gypsum, potassium chloride, and calcium phosphate. Communications in Soil Science and Plant Analysis 31:2523-33. doi:10.1080/00103620009370606.

Pegoraro, R. F., I. R. Silva, R. F. Novais, E. S. Mendonça, V. H. Alvarez, V. F. N. Nunes, F. M. Fonseca, and T. J. Smyth. 2005. Diffusive flux of cationic micronutrients in two oxisols as affected by low-molecular-weight organic acids and cover-crop residue. Journal of Plant Nutrition and Soil Science 168:334-41. doi:10.1002/jpln.200421455. 
Pegoraro, R. F., I. R. Silva, R. F. Novais, E. S. Mendonça, F. O. Gebrim, and F. F. Moreira. 2006. Diffusive flux and bioavailability of micronutrients in soils: Influence of liming, soil texture and green manure. Revista Brasileira de Ciência do Solo 30:859-68. doi:10.1590/S0100-06832006000500012.

Ryan, P. R., E. Delhaize, and D. L. Jones. 2001. Function and mechanism of organic anion exudation from plant roots. Annual Review of Plant Physiology and Plant Molecular Biology 52:527-60. doi:10.1146/annurev.arplant.52.1.527.

Silva, S. R., N. F. Barros, and L. M. Costa. 2006a. Physical attributes of two oxisols affected by soil compaction. Revista Brasileira de Engenharia Agrícola eAmbiental 10:842-47. doi:10.1590/S1415-43662006000400009.

Silva, S. R., N. F. Barros, and C. M. Souza. 2008. Effect of soil compaction on diffusive flux of phosphorus and zinc in two oxisols. Revista Ceres 55:619-24.

Silva, S. R., N. F. Barros, and J. E. B. Vilas Boas. 2006b. Eucalyptus growth and nutrition as affected by Latosol compaction at different moistures. Revista Brasileira de Ciência do Solo 30:759-68. doi:10.1590/S010006832006000500001.

Stevenson, F. J., and M. S. Ardakani. 1972. Organic matter reactions involving micronutrients in soils. In Micronutrients in agriculture, eds. J. J. Mortvedt, P. M. Giordano, and W. L. Lindsay, 79-114. Madison, WI: Soil Science Society of America.

Tandy, S., S. Mundus, J. Yngvesson, T. C. De Bang, E. Lombi, J. K. Schjoerring, and S. Husted. 2011. The use of DGT for prediction of plant available copper, zinc and phosphorus in agricultural soil. Plant and Soil 346:167-80. doi:10.1007/s11104-011-0806-y.

Temminghoff, E. J. M., S. E. A. T. M. Van Der Zee, and F. A. M. DeHaan. 1997. Copper mobility in a coppercontaminated sandy soil as affected by $\mathrm{pH}$ and solid and dissolved organic matter. Environmental Science \& Technology 31:1109-15. doi:10.1021/es9606236.

Tolon-Becerra, A., M. Tourn, G. F. Botta, and X. Lastra-Bravo. 2011. Effects of different tillage regimes on soil compaction, maize (Zea mays L.) seedling emergence and yields in the eastern Argentinean Pampas region. Soil and Tillage Research 117:184-90. doi:10.1016/j.still.2011.10.003.

Warncke, D. D., and S. A. Barber. 1972. Diffusion of $\mathrm{Zn}$ in soils: II. The influence of soil bulk density and its interaction with soil moisture. Soil Science Society of America Journal 36:42-46. doi:10.2136/ sssaj1972.03615995003600010009x. 